\title{
Hydrogen-Bonding-Aided Fabrication of Wood Derived Cellulose Scaffold/Aramid Nanofiber into High-Performance Bulk Material
}

\author{
Xiaoshuai Han, Weijie Wu, Jingwen Wang, Zhiwei Tian and Shaohua Jiang *(D) \\ Jiangsu Co-Innovation Center of Efficient Processing and Utilization of Forest Resources, \\ International Innovation Center for Forest Chemicals and Materials, College of Materials Science and \\ Engineering, Nanjing Forestry University, Nanjing 210037, China; hxs141424@njfu.edu.cn (X.H.); \\ 18751958661@163.com (W.W.); w571948261jw@163.com (J.W.); tianviatian@163.com (Z.T.) \\ * Correspondence: shaohua.jiang@njfu.edu.cn
}

Citation: Han, X.; Wu, W.; Wang, J.; Tian, Z.; Jiang, S. Hydrogen-BondingAided Fabrication of Wood Derived Cellulose Scaffold/Aramid Nanofiber into High-Performance Bulk Material. Materials 2021, 14, 5444. https:// doi.org/10.3390/ma14185444

Academic Editors: George Mantanis and Magdalena Broda

Received: 28 August 2021

Accepted: 17 September 2021

Published: 20 September 2021

Publisher's Note: MDPI stays neutral with regard to jurisdictional claims in published maps and institutional affiliations.

Copyright: (c) 2021 by the authors. Licensee MDPI, Basel, Switzerland. This article is an open access article distributed under the terms and conditions of the Creative Commons Attribution (CC BY) license (https:/ / creativecommons.org/licenses/by/ $4.0 /)$.

Abstract: Preparing a lightweight yet high-strength bio-based structural material with sustainability and recyclability is highly desirable in advanced applications for architecture, new energy vehicles and spacecraft. In this study, we combined cellulose scaffold and aramid nanofiber (ANF) into a high-performance bulk material. Densification of cellulose microfibers containing ANF and hydrogen bonding between cellulose microfibers and ANF played a crucial role in enhanced physical and mechanical properties of the hybrid material. The prepared material showed excellent tensile strength (341.7 MPa vs. 57.0 MPa for natural wood), toughness $\left(4.4 \mathrm{MJ} / \mathrm{m}^{3} \mathrm{vs} .0 .4 \mathrm{MJ} / \mathrm{m}^{3}\right.$ for natural wood) and Young's modulus (24.7 GPa vs. 7.2 GPa for natural wood). Furthermore, due to low density, this material exhibited a superior specific strength of $285 \mathrm{MPa} \cdot \mathrm{cm}^{3} \cdot \mathrm{g}^{-1}$, which is remarkably higher than some traditional building materials, such as concrete, alloys. In addition, the cellulose scaffold was infiltrated with ANFs, which also improved the thermal stability of the hybrid material. The facile and top-down process is effective and scalable, and also allows one to fully utilize cellulose scaffolds to fabricate all kinds of advanced bio-based materials.

Keywords: wood; cellulose scaffolds; aramid nanofibers; densification; hydrogen bonding; mechanical properties

\section{Introduction}

Structural materials with lightweight yet superior mechanical performance have always been a research hotspot in the field of engineering, construction and architecture. Natural wood is a very important kind of structural materials for building and furniture due to its low cost, easy processing and abundant [1-3]. However, the physical and mechanical performance of natural wood cannot meet the demand for advanced engineering materials [4-6]. Based on this, quality optimization process for natural wood is an effective strategy to achieve the high value application of wood [7-9].

In recent years, partial or full delignification pretreatment while retaining hierarchical structure of the natural wood has been a strong focus due to their excellent mechanical properties and promising serve as functionality for advanced composite materials [10-15]. After delignification, the following processes, such as polymer matrix impregnation and densification processes, were used to fabricate structure-retaining cellulosic composites with improved mechanical performance and novel functionalities [16-23] such as Yano et al. impregnated phenol formaldehyde (PF) resin into delignified wood, following by compression to different density levels and studied mechanical properties. The results showed the bending strength up to $670 \mathrm{MPa}$ and elastic modulus up to $62 \mathrm{GPa}$ [24]. Frey et al. investigated the mechanical performance of delignified spruce wood under tensile loading. The largest densification resulted in a highest density of around $1.1 \mathrm{~g} / \mathrm{cm}^{3}$, inducing 
$\sim 270 \mathrm{MPa}$ tensile strength and $\sim 35 \mathrm{GPa}$ elastic modulus even without inserting any matrix for resisting force [11]. For densification approaches, our previous research has proved that samples compressed at higher moisture content (MC) $(18 \% \mathrm{MC})$ had a better mechanical performance. More importantly, the strength and fracture toughness, which is generally mutually exclusive performance can be simultaneously improved due to water moleculeinduced hydrogen bonding between aligned cellulose nanofibers [25-27]. Based on above conclusions, the wood derived cellulose scaffold retaining inherent hierarchical structure can be processed into superior mechanical advanced material by inserting substance that can trigger more hydrogen bonding between cellulose microfibers under compression at certain moisture content.

As a kind of novel nanofibers, aramid nanofiber (ANF) has always been a research focus. It is usually obtained from commercial poly(p-phenylene terephthalamide) (PPTA) threads by "top-down" approach [28,29]. Similarly with other nanofiber, ANF exhibits anisotropic properties, nanoscale morphologies, large aspect ratio and high specific surface area. More impressively, ANF also inherits excellent mechanical performance, water resistance and thermal stability [30-33]. So far, ANF has been extensively applied in the reinforcement for polymer composites, such as polyvinyl alcohol (PVA) [34], poly(ethyleneoxide) (PEO) [35], epoxy resin [36] and cellulose nanofiber composite [37].

Inspired by the superior performances of cellulosic scaffold and ANF, herein, we reported a versatile strategy to fabricate high-performance material with superior mechanical performance and good thermal stability via vacuum dipping technique and densification process.

\section{Materials and Methods}

\subsection{Materials and Chemicals}

Basswood with dimensions of $50 \times 30 \times 10 \mathrm{~mm}^{3}$ (longitudinal $\times$ tangential $\times$ radial) was used in this work. Kevlar 29 yarn, produced by DuPont, was provide from Changzhou Hualike New Materials Co., Ltd. (Jiangsu, China) Sodium chlorite $\left(\mathrm{NaClO}_{2}\right.$, $80 \%)$, sulfuric acid $\left(\mathrm{H}_{2} \mathrm{SO}_{4}, 72 \%\right)$, acetic acid $(\mathrm{HAc}, 99.7 \%)$, sodium hydroxide $(\mathrm{NaOH}, 97 \%)$, dimethyl sulfoxide (DMSO), potassium hydroxide $(\mathrm{KOH})$, acetone $(99.8 \%)$ and hexane $(99.8 \%)$ were purchased from Fisher Scientific (Waltham, MA, USA). All chemicals were used as received without further purification. Deionized (DI) water was used for whole experimental process.

\subsection{Preparation of Aramid Nanofiber (ANF) Suspension}

A $2 \mathrm{mg} / \mathrm{mL}$ ANF suspension was prepared referring to previous reports $[38,39]$. Specifically, $1 \mathrm{~g}$ of bulk Kevlar 29 and $0.5 \mathrm{~g} \mathrm{KOH}$ were added into $500 \mathrm{~mL}$ DMSO, which was then magnetically stirred for 1 week under ambient conditions forming a dark red, viscous suspension of ANF (Figure S1).

\subsection{Fabrication of Aligned Cellulose Microfiber/ANF Hybrid Material}

In order to obtain aligned cellulose scaffold (CS), natural basswood (NW) sample was chemically treated to remove lignin and hemicellulose according to our previous work (Figure S2) $[25,40]$. The obtained CS was infiltrated with $0.5 \mathrm{mg} / \mathrm{mL}$ ANF suspension. Then, the impregnated CS was subjected to solvent-exchange method to remove DMSO, following by air drying $\left(\mathrm{CS}_{\mathrm{AD}}\right)$ to $18 \% \mathrm{MC}$. Finally, above sample was densified along radial direction using a hot press (ZG-50TSD, Dongguan Zhenggong Electromechanical Equipment Technology Co., Ltd., Dongguan, China) under $35 \mathrm{MPa}$ pressure for $10 \mathrm{~min}$ to fabricate aligned cellulose microfiber/ANF hybrid material $\left(\mathrm{CCS}_{\mathrm{AD}-\mathrm{ANF}}\right)$. After densification, the densified sample was dried at $80^{\circ} \mathrm{C}$ for $24 \mathrm{~h}$ and then cooled to room temperature for further characterization. 


\subsection{Chemical Component Analysis}

The cellulose, hemicellulose and lignin contents of NW and CS was tested based on standard TAPPI T $222 \mathrm{om}-2$ method [41]. Specifically, $200 \mathrm{mg}$ of dry powdered sample was fully acid-hydrolyzed using $3 \mathrm{~mL} 72 \% \mathrm{H}_{2} \mathrm{SO}_{4}$, following by adding $112 \mathrm{~mL}$ DI water and was then autoclaved at $121^{\circ} \mathrm{C}$ for $1 \mathrm{~h}$. The acid-insoluble lignin was filtered, oven-dried and weighed. The acid-soluble lignin was determined based on the absorbance at $205 \mathrm{~nm}$ using UV spectrophotometer. The sugars were analyzed by Agilent 1200 high-performance liquid chromatograph (HPLC) using a Bio-Rad Aminex 87H column. All assays were carried out in triplicate.

\subsection{Density and Porosity Tests}

The densities of NW, $\mathrm{CS}_{\mathrm{AD}}$ and $\mathrm{CCS}_{\mathrm{AD}-\mathrm{ANF}}$ were calculated from the ratios of mass to volume. The porosities of these three samples were determined as follows:

$$
\text { Porosity }(\%)=\left(1-\frac{\rho_{a}}{\rho_{c}}\right) \times 100 \%
$$

where $\rho_{a}$ is the density of the NW, $\mathrm{CS}_{\mathrm{AD}}$ and $\mathrm{CCS}_{\mathrm{AD}-\mathrm{ANF}}$ samples and $\rho_{c}$ is the density of pure cellulosic specimen, taken as $1.5 \mathrm{~g} \mathrm{~cm}^{-3}$ [42].

\subsection{Fourier Transform Infrared (FTIR) Analysis}

FTIR spectrum of the samples was obtained using an Attenuated Total Reflectance Fourier Transform Infrared spectrometer (VERTEX 80V, Bruker, Germany) from 4000 to $400 \mathrm{~cm}^{-1}$ at a spectral resolution of $4 \mathrm{~cm}^{-1}$ with a total of 128 scans.

\subsection{Scanning Electron Microscopy (SEM) Analysis}

The morphologies of NW, $\mathrm{CS}_{\mathrm{AD}}$ and $\mathrm{CCS}_{\mathrm{AD}-\mathrm{ANF}}$ were characterized using Phenom XLSE-G2 Desktop Scanning Electron Microscope (Phenom-World BV, Eindhoven, Netherlands), SED mode and accelerating voltage of $10 \mathrm{kV}$. The samples were sliced using cutall microtome and then oven-dried, following by sputter-coated with Au target prior to observation.

\subsection{Mechanical Performance Tests}

The mechanical properties of all samples were tested using the 3365 universal testing machine (Instron Test Equipment Trading Co., Ltd., Hangzhou, China). Based on a standard measurement [43], all samples were produced in dog-bone shape specimens with $50 \mathrm{~mm}$ length $\times 2 \mathrm{~mm}$ width (middle section) dimensions. The specimens were fixed at both ends using a mechanical clamp and stretched along the longitudinal direction until failure. The testing was conducted using a $5 \mathrm{kN}$ load cell at $2 \mathrm{~mm} \cdot \mathrm{min}^{-1}$ rate under room conditions. At least 15 specimens were tested for every sample and average value and standard deviation were calculated.

\subsection{Thermogravimetric Analysis (TGA)}

To investigate the thermal stability of NW, $\mathrm{CS}_{\mathrm{AD}}$ and $\mathrm{CCS}_{\mathrm{AD}-\mathrm{ANF}}$, roughly $5 \mathrm{mg}$ of powdered samples were analyzed using a thermal analyzer (STA 449F3, NETZSCH, Selb, Germany). The test was performed from room temperature to $800{ }^{\circ} \mathrm{C}$ at a heating rate of $10^{\circ} \mathrm{min}^{-1}$ under nitrogen atmosphere (a flow of $20 \mathrm{~mL} / \mathrm{min}$ ).

\subsection{X-ray Diffraction (XRD) Analysis}

The XRD analysis was carried out through a Rigaku Ultima IV (Tokyo, Japan) (CuK $\alpha$ radiation with graphite monochromator, $40 \mathrm{kV}$ and $30 \mathrm{~mA}$ ). The patterns were obtained between $5^{\circ}$ and $90^{\circ} 2 \theta$ with $0.02^{\circ}$ steps and scan speed of $10^{\circ} \mathrm{min}^{-1}$. The degree of crystallinity (Cr) was calculated using the empirical formular by Segal et al. [44].

$$
\operatorname{Cr}(\%)=\frac{I_{200}-I_{a m}}{I_{200}} \times 100 \%
$$


where $I_{200}$ represented the peak at the maximum intensity that relates to the (200) lattice plane and $I_{a m}$ is the minimum intensity value between the highest two peaks.

\section{Results}

Figure 1 shows the complete process of preparing a high-performance cellulosic bulk material with the participation of ANF. Specifically, the material was fabricated following a three-step process including (1) delignification to remove most linin and some hemicelluloses, which can explore more cellulose microfibers, increasing hydrogen bonding sites; (2) CS was impregnated using ANF, which will take part in subsequent hydrogen bonding assembly of high-performance cellulosic materials; and (3) mechanical compression of infiltrated cellulosic materials with $18 \%$ moisture content to induce more hydrogen bonding for enhanced mechanical properties.

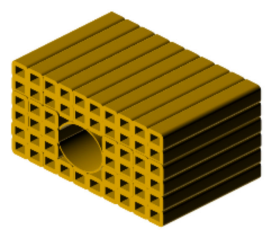

Natural wood
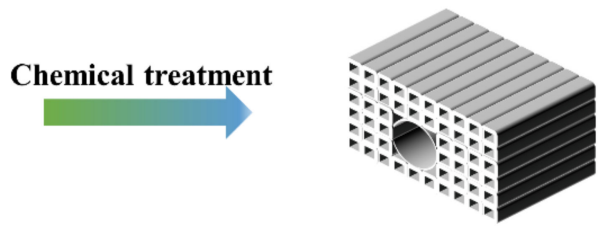

Cellulose scaffold

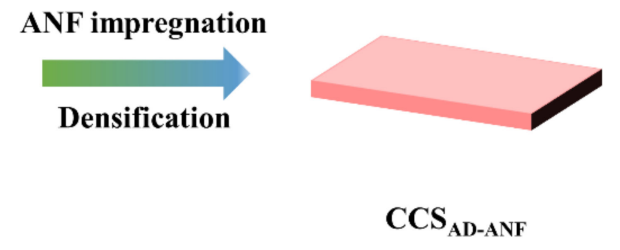

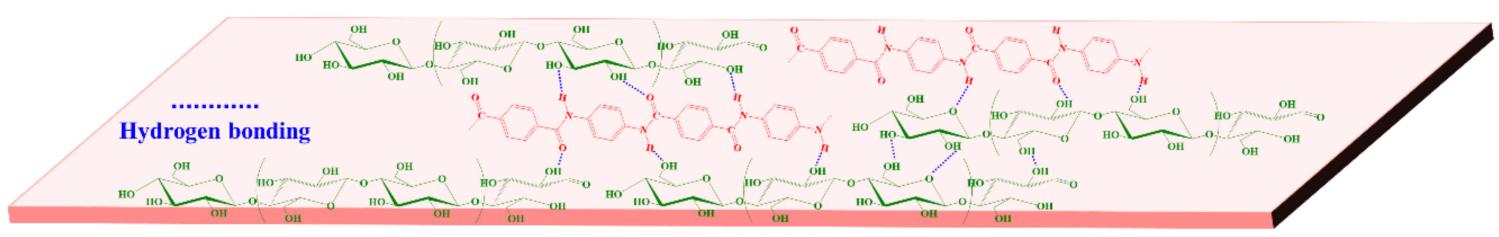

Figure 1. The preparation process of a high-performance cellulosic bulk material.

In the microstructure of wood, the lignin plays a role of adhesive, which sticks cellulose and hemicellulose together. However, its existence decreased the accessibility of cellulose, restricting possible functionalization. So, the natural basswood was subjected to sodium chlorite $\left(\mathrm{NaClO}_{2}\right)$ and sodium hydroxide $(\mathrm{NaOH})$ treatment to remove lignin and hemicellulose. Results from the delignification process showed that the delignified wood contained $80.2 \%$ cellulose, $13.5 \%$ hemicellulose and $1.7 \%$ lignin, demonstrating $38.8 \%$ hemicellulose and $93.1 \%$ lignin removal (Figure 2a). In addition, samples of each stage under preparation showed different physical performance. Compared to NW, the $\mathrm{CS}_{\mathrm{AD}}$ exhibited slightly increased density ( 0.5 vs. $0.4 \mathrm{~g} \mathrm{~cm}^{-3}$ for NW) and smaller porosity ( 66.7 vs. $73.3 \%$ for NW) due to air shrinkage (Figure $2 b$ ). The result of FTIR spectra of NW and CS also echoed the component analysis as shown in Figure 2c,d. For NW, the presence of $1584 \mathrm{~cm}^{-1}$ and $1502 \mathrm{~cm}^{-1}$ ( $C=C$ stretching vibration of the aromatic rings) represents the typical structure of lignin, while the band locating in $1237 \mathrm{~cm}^{-1}$ belongs to the C-O stretching of the aromatic rings. In addition, the peak at $1729 \mathrm{~cm}^{-1}$ is ascribed to unconjugated carbonyl $\mathrm{C}=\mathrm{O}$ in hemicellulose. After $\mathrm{NaClO}_{2}$ and $\mathrm{NaOH}$ treatment, there are not these characteristic peaks for lignin and hemicellulose in CS sample. 

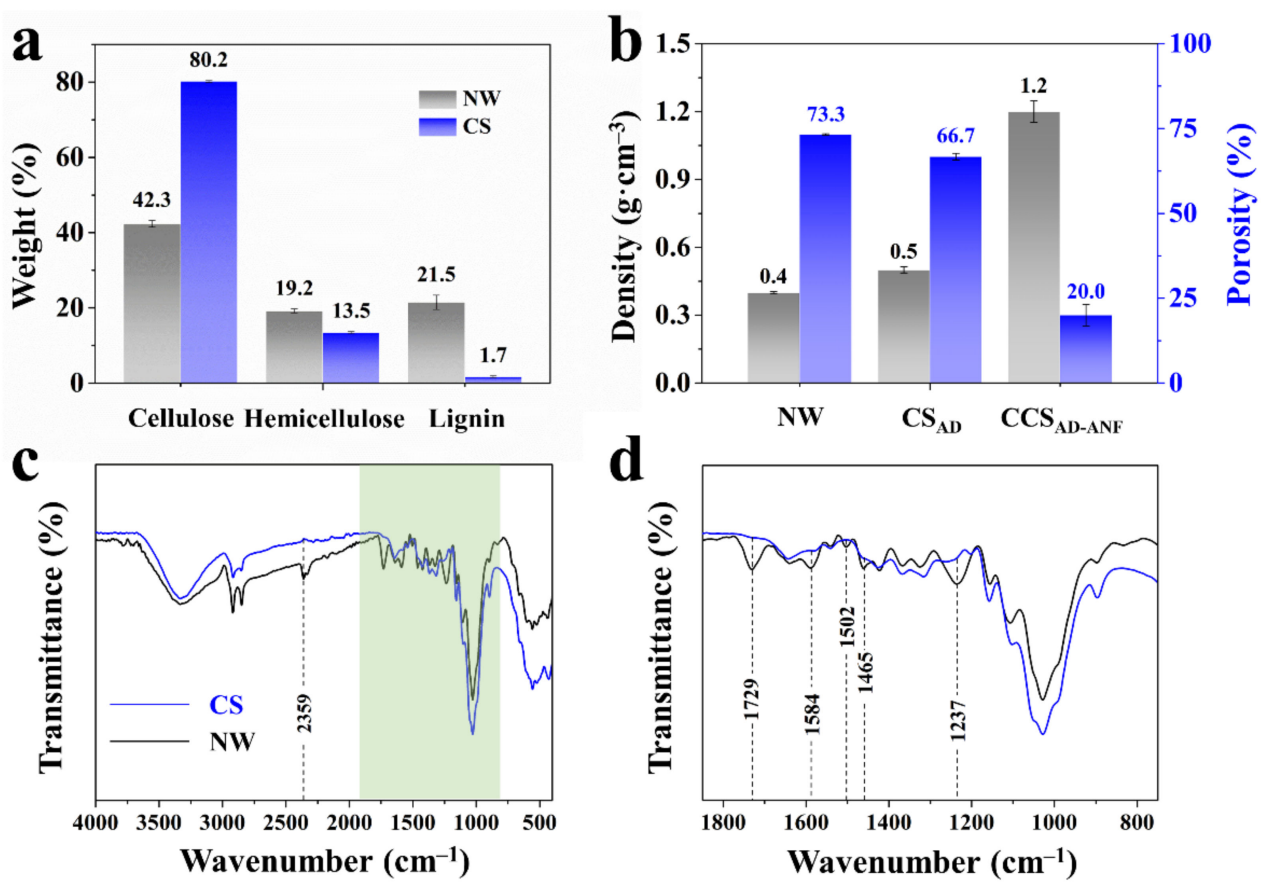

Figure 2. The comparison of cellulose, hemicellulose and lignin content in NW and CS (a). Density and porosity of NW, CS $\mathrm{AD}_{\mathrm{AD}}$ and $\mathrm{CCS}_{\mathrm{AD}-\mathrm{ANF}}(\mathbf{b})$. FTIR spectra of NW (c) and CS (d).

The morphologies of NW, $\mathrm{CS}_{\mathrm{AD}}$ and $\mathrm{CCS}_{\mathrm{AD}-\mathrm{ANF}}$ were shown in Figure 3. Due to drying shrinkage and densification, the thickness of $\mathrm{CS}_{\mathrm{AD}}$ and $\mathrm{CCS}_{\mathrm{AD}-\mathrm{ANF}}$ gradually decreased in macroscopic level (Figure $3 \mathrm{a}, \mathrm{d}, \mathrm{g}$ ). In case of SEM, the transverse section of NW looks like honeycomb, comprising of vessel and tracheid cells (Figure $3 \mathrm{~b}$ and Figure S3a,b). The longitudinal microstructure of vessel and tracheid cells of NW is clear and smooth (Figure $3 \mathrm{c}$ and Figure S3c,d). After delignification, ANF impregnation and air-drying, the intrinsic honeycomb structure was destroyed and wood cell walls approached each other to form layer-by-layer structure (Figure 3e and Figure S4). In addition, the longitudinal section SEM image of $\mathrm{CS}_{\mathrm{AD}}$ showed that the wood cells of vessel and tracheid became rough and appeared some aligned cellulose microfibers (Figure $3 f$ and Figure S5). After absorbing certain water vapor $(18 \% \mathrm{MC}), \mathrm{CS}_{\mathrm{AD}}$ samples were subjected to compression under $35 \mathrm{MPa}$ pressure. Compared to $\mathrm{NW}$ and $\mathrm{CS}_{\mathrm{AD}}$, transverse section images of $\mathrm{CCS}_{\mathrm{AD}-\mathrm{ANF}}$ exhibited very dense and hard microstructure: wood cell lumen disappeared and cell walls closely bonded together (Figure 3h,i and Figure S6). The underlying cause for the dense and hard microstructure could be explained in three aspects. Firstly, a certain moisture content can effectively soften stiff cellulose microfibers within wood cell walls and water molecule can play a bridge role of hydrogen bonding between cellulose microfibers under compression. Secondly, densification process can obviously eliminate steric hindrance, inducing wood cell walls and cellulose microfibers to tightly intertwine and densely pack together by forming hydrogen bonding [25]. Thirdly, the impregnated ANF can fill up to void gap under compression and it also assist cellulose microfibers to form more hydrogen bonding between amide-group and hydroxyl groups. The above three factors played a significant role in forming dense and hard structure of $\mathrm{CCS}_{\mathrm{AD}-\mathrm{ANF}}$, which will help to improve the mechanical properties of product. 

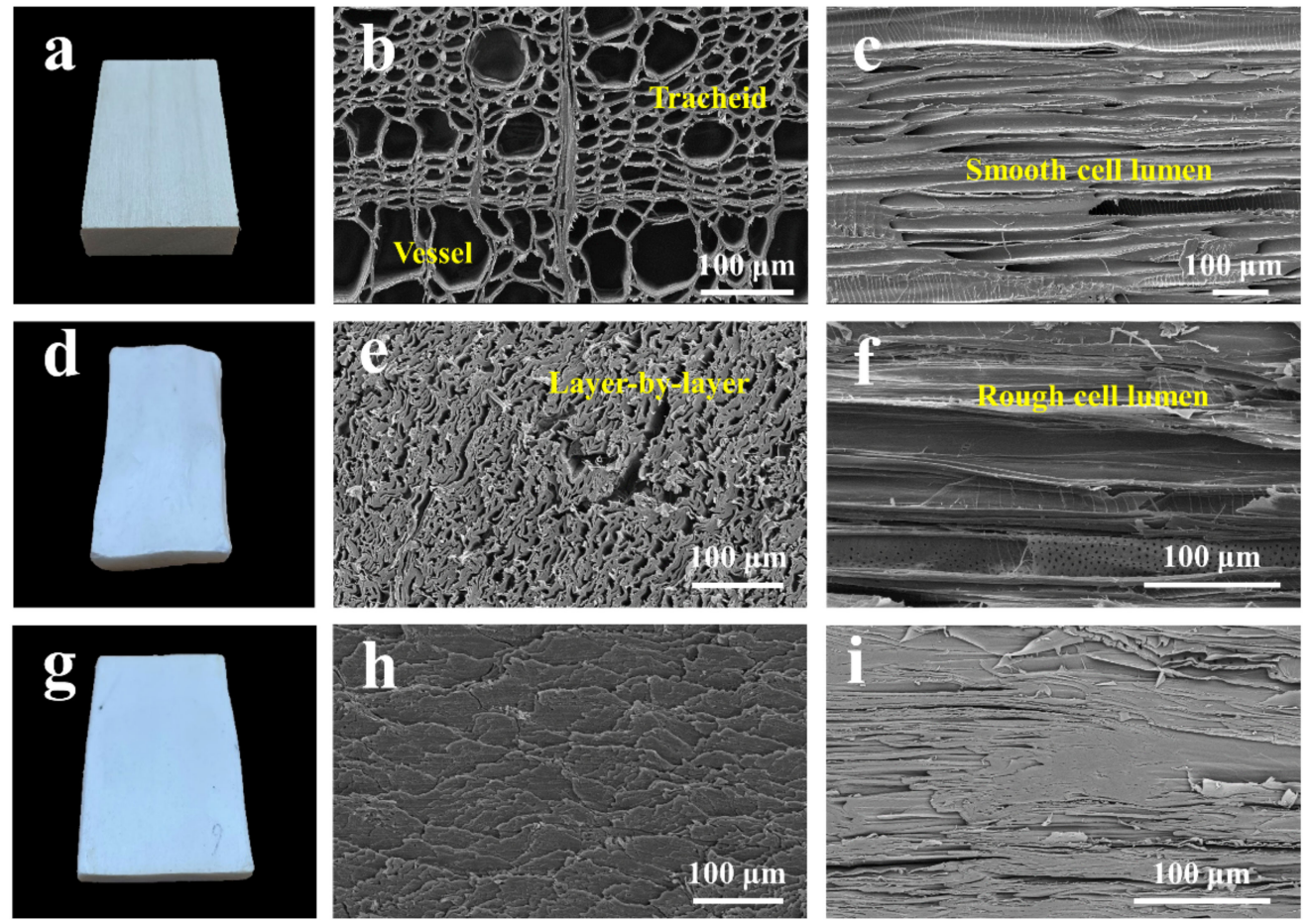

Figure 3. Photographs of (a) NW, (d) $\mathrm{CS}_{\mathrm{AD}}$ and (g) $\mathrm{CS}_{\mathrm{AD}-\mathrm{ANF}}$. Transverse SEM images of (b) NW, (e) $\mathrm{CS}_{\mathrm{AD}}$ and (h) $\mathrm{CCS}_{\mathrm{AD}-\mathrm{ANF}}$. Longitudinal SEM images of (c) NW, (f) $\mathrm{CS}_{\mathrm{AD}}$ and (i) $\mathrm{CCS}_{\mathrm{AD}-\mathrm{ANF}}$.

The mechanical properties of NW, $\mathrm{CS}_{\mathrm{AD}}$ and $\mathrm{CCS}_{\mathrm{AD}-\mathrm{ANF}}$ are presented in Figure 4 . Compared to NW, the $\mathrm{CS}_{\mathrm{AD}}$ sample possessed improved strength (141.2 vs. $\left.57.0 \mathrm{MPa}\right)$, toughness (1.0 vs. $0.4 \mathrm{MJ} / \mathrm{m}^{3}$ ) and Young's modulus (16.5 vs. $7.2 \mathrm{GPa}$ ) (Figure $\left.4 \mathrm{~b}\right)$. The enhancement of mechanical performance was attributed to water-induced hydrogen bonding between cellulose microfibers within CS cell walls. As for the $\mathrm{CCS}_{\mathrm{AD}-\mathrm{ANF}}$, the tensile strength (341.7 MPa), toughness $\left(4.4 \mathrm{MJ} / \mathrm{m}^{3}\right)$, Young's modulus (24.7 GPa) and density $\left(1.2 \mathrm{~g} / \mathrm{cm}^{3}\right)$ were more than 5, 10, 2.4, 2 times higher than those of NW, respectively (Figure $4 \mathrm{~b}, \mathrm{c}$ ), which is consistent with the SEM images result. Both the microscopic structure and macroscopic mechanical properties of the NW, $\mathrm{CS}_{\mathrm{AD}}$ and $\mathrm{CCS}_{\mathrm{AD}-\mathrm{ANF}}$ implied that lignin removal facilitated hydrogen bonding between cellulose microfibers, resulting in mechanical performance improvement. More importantly, the physical and mechanical properties were strikingly enhanced due to ANF impregnation. The ANF can take part in hydrogen bonding assembly between cellulose microfibers and it also can be inserted into micro defect under compression, resulting in very dense structure and excellent physical and mechanical performance. The specific strength is a kind of very important index in practical application. A comparison of specific tensile strength with conventional construction materials and lignocellulosic structural materials, including concrete, stainless steel (304, SS), aluminum alloy (6061-T6, AA), magnesium alloy (MA), strong and tough material (STM) [40], bio-based laminate (BBL) [19], ultrastrong and tough material (UTM) [25] and high-strength composite (HSC) [16] was plotted in Figure 4d. The specific strength of $\mathrm{CCS}_{\mathrm{AD}-\mathrm{ANF}}$ is significantly greater than that of traditional building materials and it even can match high-performance wooden structural composites. In addition, the specific strength is a very necessary benefit for the applications in areas, such as new energy vehicles, spacecraft, where lightweight high strong properties are required. 

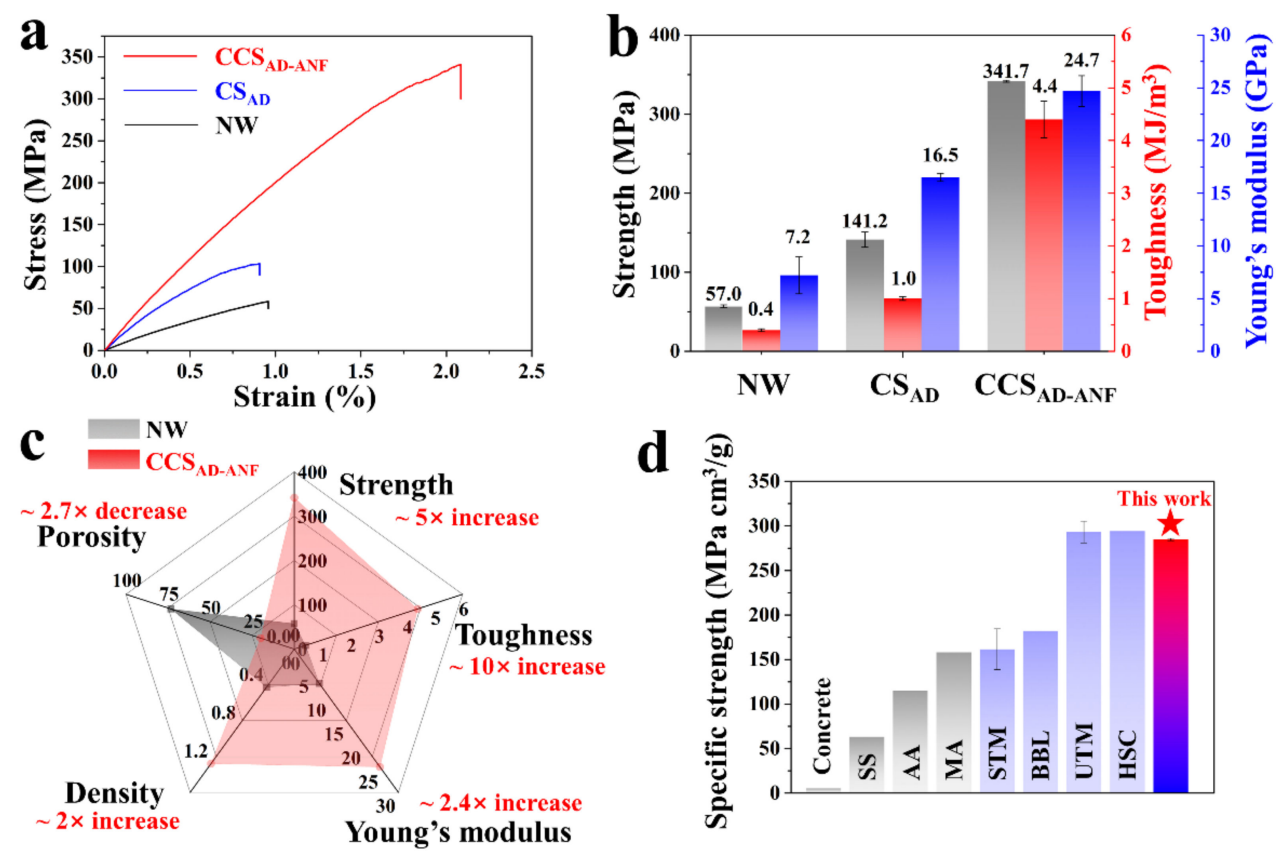

Figure 4. Mechanical performance of NW, $\mathrm{CS}_{\mathrm{AD}}$ and $\mathrm{CCS}_{\mathrm{AD}-\mathrm{ANF}}$. (a) Tensile stress-strain curves for $\mathrm{NW}, \mathrm{CS}_{\mathrm{AD}}$ and $\mathrm{CCS}_{\mathrm{AD}-\mathrm{ANF}}$ (b) Tensile strength, toughness and Young's modulus values derived from the tensile stress-strain curves of NW, $\mathrm{CS}_{\mathrm{AD}}$ and $\mathrm{CCS}_{\mathrm{AD}-\mathrm{ANF}}$. (c) Comparison of the physical and mechanical properties of NW and $\mathrm{CCS}_{\mathrm{AD}-\mathrm{ANF}}$. (d) Comparison of the specific strength of $\mathrm{CCS}_{\mathrm{AD}-\mathrm{ANF}}$, concrete, stainless steel (304, SS), aluminum alloy (6061-T6, AA), magnesium alloy (MA), strong and tough material (STM), bio-based laminate (BBL), ultrastrong and tough material (UTM) and high-strength composite (HSC).

The XRD patterns of NW, $\mathrm{CS}_{\mathrm{AD}}$ and $\mathrm{CCS}_{\mathrm{AD}-\mathrm{ANF}}$ were shown in Figure 5a. Comparing the three curves, the peak position did not change, indicating that the delignification and ANF modification did not destroy the crystalline structure of cellulose. However, the significant difference of these three samples was the crystalline degree values: the $\mathrm{Cr}$ of $\mathrm{NW}, \mathrm{CS}_{\mathrm{AD}}$ and $\mathrm{CCS}_{\mathrm{AD}-\mathrm{ANF}}$ were $37.8 \%, 56.5 \%$ and $67.4 \%$, respectively. The delignification process removed amorphous lignin and hemicellulose and preserved the crystal cellulose. Moreover, the high crystalline ANF impregnation endowed the $\mathrm{CCS}_{\mathrm{AD}-\mathrm{ANF}}$ with high crystallinity. High crystallinity can help improve mechanical properties of samples and the excellent mechanical performance of $C C S_{A D-A N F}$ is consistent with the information reflected by the XRD results. The strong interactions between cellulose microfibers and ANF were reflected by FTIR in Figure $5 b$. The absorption peaks of about $3300 \mathrm{~cm}^{-1}$ and $1640 \mathrm{~cm}^{-1}$ are corresponded to the $\mathrm{N}-\mathrm{H}$ and $\mathrm{C}=\mathrm{O}$ stretching vibration of $\mathrm{ANF}$, respectively $[45,46]$. Figure $5 \mathrm{~b}$ showed that the $\mathrm{N}-\mathrm{H}$ and $\mathrm{C}=\mathrm{O}$ absorption peaks of the $\mathrm{CCS}_{\mathrm{AD}-\mathrm{ANF}}$ was significantly increased compared with $\mathrm{CS}_{\mathrm{AD}}$ sample, indicating the ANF was successfully infiltrated into $\mathrm{CS}$ structure. In addition, the $\mathrm{N}-\mathrm{H}$ and $\mathrm{C}=\mathrm{O}$ chemical signal that differentiates the $\mathrm{CS}_{\mathrm{AD}}$ from $\mathrm{CCS}_{\mathrm{AD}-\mathrm{ANF}}$ is the apparently upshift and the higher energy of these molecular vibrations is related to the stronger hydrogen bonds in the material $[32,34]$. Meanwhile, there's a blue-shift of $\mathrm{CCS}_{\mathrm{AD}-\mathrm{ANF}}$ sample in $3300 \mathrm{~cm}^{-1}$ absorption peak, which can be ascribed to new hydrogen bonding formed between N-H groups of ANF and the O-H groups of cellulose microfibers (Figure S7). 

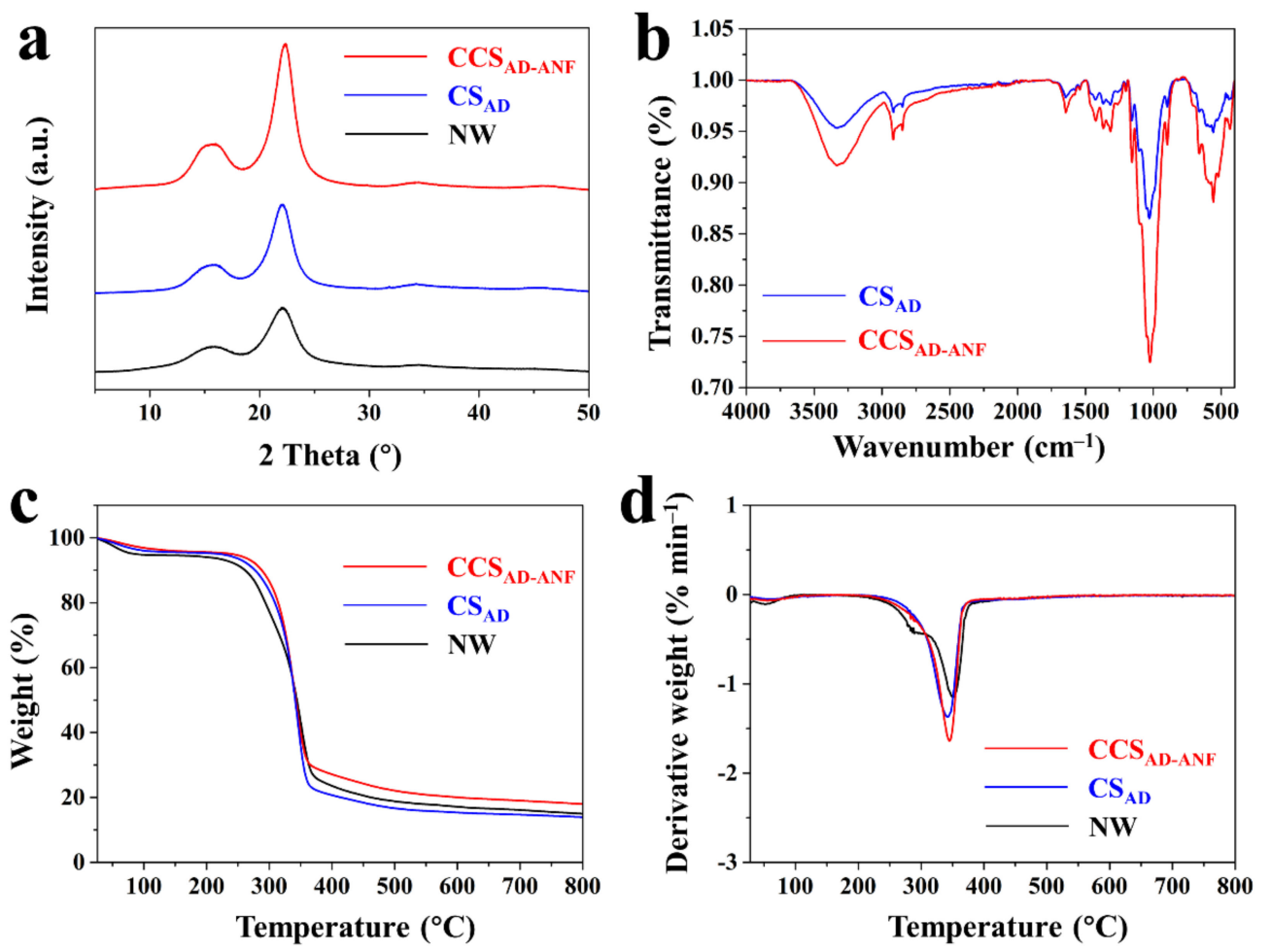

Figure 5. (a) XRD patterns of NW, $\mathrm{CS}_{\mathrm{AD}}$ and $\mathrm{CCS}_{\mathrm{AD}-\mathrm{ANF}}$ (b) FTIR curves of $\mathrm{CS}_{\mathrm{AD}}$ and $\mathrm{CCS}_{\mathrm{AD}-\mathrm{ANF}}$. TGA (c) and DTG (d) curves of NW, $\mathrm{CS}_{\mathrm{AD}}$ and $\mathrm{CCS}_{\mathrm{AD}-\mathrm{ANF}}$.

The TG and DTG curves of NW, $\mathrm{CS}_{\mathrm{AD}}$ and $\mathrm{CCS}_{\mathrm{AD}-\mathrm{ANF}}$ were presented in Figure $5 \mathrm{c}, \mathrm{d}$. The natural wood is commonly vulnerable to thermal decomposition and its three main components (cellulose, hemicellulose and lignin) have different thermal stability due to their inherent structure $[47,48]$. Typically, the pyrolysis of hemicellulose occurred at $220-315{ }^{\circ} \mathrm{C}$ and the thermal degradation of cellulose mainly happened at $315-400{ }^{\circ} \mathrm{C}$. Meanwhile, the lignin has a pyrolysis between $150^{\circ} \mathrm{C}$ and $600{ }^{\circ} \mathrm{C}$. Due to hemicellulose and lignin removal, the $\mathrm{CS}_{\mathrm{AD}}$ samples had a better thermal stability than NW between $220-315{ }^{\circ} \mathrm{C}$. It was noted that the $\mathrm{CCS}_{\mathrm{AD}-\mathrm{ANF}}$, exhibited a better thermal stability. This was mainly due to ANF unique inherent microstructure, which has linear benzene ring structure, intermolecular hydrogen bonds and good crystallinity $[49,50]$. In addition, the initial weight loss before $220^{\circ} \mathrm{C}$ was also attributed to the evaporation of free water and adsorbed water. The compression process of $\mathrm{CS}_{\mathrm{ANF}}$ under $18 \%$ moisture content can make the free water molecule become structural water by taking part in hydrogen bonding between hydroxyl groups (CS) and amide groups (ANF). So, the $\mathrm{CCS}_{\mathrm{AD}-\mathrm{ANF}}$ samples had a better thermal stability than NW and $\mathrm{CS}_{\mathrm{AD}}$ samples before $220^{\circ} \mathrm{C}$.

\section{Conclusions}

Herein, we presented a successful preparation of a cellulose scaffold/ANF hybrid bulk composite with outstanding mechanical performance and thermal stability through delignification, ANF impregnation and densification. Air drying process of delignified wood brings a dense structure, leading to improved mechanical properties (2.5 times for tensile strength, 2.5 times for toughness and 2.3 times for Young's modulus) as compared to natural wood. The densification of cellulose scaffold impregnated with ANF endowed cellulose scaffold/ANF hybrid bulk composite with a more compact cementlike microstructure, inducing a superior mechanical properties and thermal stability. The 341.7 MPa tensile strength, $4.4 \mathrm{MJ} / \mathrm{m}^{3}$ toughness and $24.7 \mathrm{GPa}$ Young's modulus of cellulose microfibers / ANF hybrid bulk material approximately 5, 10 and 2.4 times higher, respectively, as compared to those of natural wood. The above results indicated that ANF 
played a very important role in assisting the assembly of cellulose scaffold into a good thermal stability and superior mechanical material, by forming hydrogen bonding with cellulose microfibers under compression. The product could be used in the design of highperformance biobased hybrid material for application in wooden architecture, automotive equipment and spacecraft.

Supplementary Materials: The following are available online at https:/ /www.mdpi.com/article/ 10.3390/ma14185444/s1. Figure S1: The preparation of aramid nanofiber (ANF) and molecular structure of ANF, Figure S2: Delignification process of natural wood by $\mathrm{NaClO}_{2}$ and $\mathrm{NaOH}$ treatment, Figure S3: SEM images of NW, Figure S4: SEM transverse images of $\mathrm{CS}_{\mathrm{AD}}$, Figure S5: SEM longitudinal images of $\mathrm{CS}_{\mathrm{AD}}$, Figure S6: SEM transverse images of $\operatorname{CCS}_{\mathrm{AD}-\mathrm{ANF}}(\mathrm{a}, \mathrm{b})$ and SEM longitudinal images of $\mathrm{CCS}_{\mathrm{AD}-\mathrm{ANF}}(\mathrm{c}, \mathrm{d})$, Figure S7: Magnified FTIR spectra for CS and $\mathrm{CCS}_{\mathrm{AD}-\mathrm{ANF}}$.

Author Contributions: Conceptualization, X.H. and S.J.; methodology, W.W. and J.W.; formal analysis, J.W. and W.W.; investigation, X.H. and Z.T.; data curation, Z.T.; writing-original draft preparation, X.H.; writing-review and editing, X.H. and S.J.; supervision, S.J.; project administration, X.H. and S.J.; funding acquisition, S.J. All authors have read and agreed to the published version of the manuscript.

Funding: This research was funded by the National Natural Science Foundation of China, grant number 51803093 and Natural Science Foundation of Jiangsu Province, grant number BK20180770.

Institutional Review Board Statement: Not applicable.

Informed Consent Statement: Not applicable.

Data Availability Statement: The data presented in this study are available upon request from the corresponding author.

Conflicts of Interest: The authors declare no conflict of interest.

\section{References}

1. Song, J.W.; Chen, C.J; Zhu, S.Z.; Zhu, M.W.; Dai, J.Q.; Ray, U.; Li, Y.J; Kuang, Y.D.; Li, Y.F.; Quispe, N.; et al. Processing bulk natural wood into a high-performance structural material. Nature 2018, 554, 224-228. [CrossRef]

2. Ding, L.; Han, X.; Jiang, S. Impregnation of poplar wood with multi-functional composite modifier and induction of in-situ polymerization by heating. J. Wood Chem. Technol. 2021, 41, 220-228. [CrossRef]

3. Zhang, L.; Chen, Z.; Dong, H.; Fu, S.; Ma, L.; Yang, X. Wood plastic composites based wood wall's structure and thermal insulation performance. J. Bioresour. Bioprod. 2021, 6, 65-74. [CrossRef]

4. Huang, C.; Chui, Y.; Gong, M.; Chana, F. Mechanical behaviour of wood compressed in radial direction: Part II. Influence of temperature and moisture content. J. Bioresour. Bioprod. 2020, 5, 266-275. [CrossRef]

5. Huang, C.; Gong, M.; Chui, Y.; Chan, F. Mechanical behaviour of wood compressed in radial direction-part I. New method of determining the yield stress of wood on the stress-strain curve. J. Bioresour. Bioprod. 2020, 5, 186-195. [CrossRef]

6. Wang, F.; Cheong, J.Y.; Lee, J.; Ahn, J.; Duan, G.G.; Chen, H.L.; Zhang, Q.; Kim, I.D.; Jiang, S.H. Pyrolysis of Enzymolysis-Treated Wood: Hierarchically Assembled Porous Carbon Electrode for Advanced Energy Storage Devices. Adv. Funct. Mater. 2021, 31, 2101077. [CrossRef]

7. Wang, C.; Yang, Z.; Wang, X.; Yu, Q. New research progress of functional wood. J. For. Eng. 2019, 4, 10-18.

8. Chen, L.; Xu, Z.W.; Wang, F.; Duan, G.G.; Xu, W.H.; Zhang, G.Y.; Yang, H.Q.; Liu, J.B.; Jiang, S.H. A flame-retardant and transparent wood/polyimide composite with excellent mechanical strength. Compos. Commun. 2020, 20, 100355. [CrossRef]

9. Wu, G.; Sun, J.; Huang, C.; Ren, H.; Zhao, R. Research progress on mechanical properties of tenon-mortise joints in traditional Chinese wood structures. J. For. Eng. 2020, 5, 29-37.

10. Keplinger, T.; Wittel, F.K.; Ruggeberg, M.; Burgert, I. Wood Derived Cellulose Scaffolds-Processing and Mechanics. Adv. Mater. 2021, 33, 2001375. [CrossRef]

11. Frey, M.; Widner, D.; Segmehl, J.S.; Casdorff, K.; Keplinger, T.; Burgert, I. Delignified and Densified Cellulose Bulk Materials with Excellent Tensile Properties for Sustainable Engineering. ACS Appl. Mater. Interfaces 2018, 10, 5030-5037. [CrossRef] [PubMed]

12. Nishiyama, Y. Retrieving Structural Information from Scattering and Attenuation Data of Transparent Wood and (Nano) paper. J. Bioresour. Bioprod. 2021, 6, 187-194.

13. Pan, M.; Ding, C.; Zhang, S.; Huang, Y. Progress on flame retardancy of wood plastic composites. J. For. Eng. 2020, 5, 1-12.

14. Xu, F.; Chen, Y.; You, T.; Mao, J.; Zhang, X. Research progress on mechanism of cellulose dissolution. J. For. Eng. 2019, 4, 1-7.

15. Zou, Y.; Yang, P.; Yang, L.; Li, N.; Duan, G.G.; Liu, X.H.; Li, Y.W. Boosting solar steam generation by photothermal enhanced polydopamine/wood composites. Polymer 2021, 217, 123464. [CrossRef] 
16. Tang, Q.; Zou, M.; Gao, K.; Chang, L.; Gao, L.; Guo, W. Laminating Delignified Wood Veneers toward High-Strength, FlameRetardant Composites for Structural Applications. ACS Sustain. Chem. Eng. 2021, 9, 10717-10726. [CrossRef]

17. Mi, R.Y.; Chen, C.J.; Keplinger, T.; Pei, Y.; He, S.M.; Liu, D.P.; Li, J.G.; Dai, J.Q.; Hitz, E.; Yang, B.; et al. Scalable aesthetic transparent wood for energy efficient buildings. Nat. Commun. 2020, 11, 1-9. [CrossRef]

18. Li, K.; Wang, S.N.; Chen, H.; Yang, X.; Berglund, L.A.; Zhou, Q. Self-Densification of Highly Mesoporous Wood Structure into a Strong and Transparent Film. Adv. Mater. 2020, 32, 2003653. [CrossRef]

19. Frey, M.; Schneider, L.; Razi, H.; Trachsel, E.; Faude, E.; Koch, S.M.; Masania, K.; Fratzl, P.; Keplinger, T.; Burgert, I. HighPerformance All-Bio-Based Laminates Derived from Delignified Wood. ACS Sustain. Chem. Eng. 2021, 9, 9638-9646. [CrossRef]

20. He, S.M.; Chen, C.J.; Li, T.; Song, J.W.; Zhao, X.P.; Kuang, Y.D.; Liu, Y.; Pei, Y.; Hitz, E.; Kong, W.Q.; et al. An Energy-Efficient, Wood-Derived Structural Material Enabled by Pore Structure Engineering towards Building Efficiency. Small Methods 2020 4, 1900747. [CrossRef]

21. Jakob, M.; Gaugeler, J.; Gindl-Altmutter, W. Effects of Fiber Angle on the Tensile Properties of Partially Delignified and Densified Wood. Materials 2020, 13, 5405. [CrossRef]

22. Jiang, S.; Zhou, M.; Deng, W.; Dai, H.; Fang, G.; Wu, W. High-wet-strength paper-based lignocellulosic adsorbents and its heavy metal ion adsorption properties. J. For. Eng. 2020, 5, 101-107.

23. Joseph, B.; Sagarika, V.; Sabu, C.; Kalarikkal, N.; Thomas, S. Cellulose nanocomposites: Fabrication and biomedical applications. J. Bioresour. Bioprod. 2020, 5, 223-237. [CrossRef]

24. Yano, H.; Hirose, A.; Collins, P.J.; Yazaki, Y. Effects of the removal of matrix substances as a pretreatment in the production of high strength resin impregnated wood based materials. J. Mater. Sci. Lett. 2001, 20, 1125-1126. [CrossRef]

25. Han, X.S.; Ye, Y.H.; Lam, F.; Pu, J.W.; Jiang, F. Hydrogen-bonding-induced assembly of aligned cellulose nanofibers into ultrastrong and tough bulk materials. J. Mater. Chem. A 2019, 7, 27023-27031. [CrossRef]

26. Zou, Y.; Zhao, J.Y.; Zhu, J.Y.; Guo, X.Y.; Chen, P.; Duan, G.G.; Liu, X.H.; Li, Y.W. A Mussel-Inspired Polydopamine-Filled Cellulose Aerogel for Solar-Enabled Water Remediation. ACS Appl. Mater. Interfaces 2021, 13, 7617-7624. [CrossRef] [PubMed]

27. Chen, Y.M.; Zhang, L.; Mei, C.T.; Li, Y.; Duan, G.G.; Agarwal, S.; Greiner, A.; Ma, C.X.; Jiang, S.H. Wood-Inspired Anisotropic Cellulose Nanofibril Composite Sponges for Multifunctional Applications. ACS Appl. Mater. Interfaces 2020, 12, 35513-35522. [CrossRef]

28. Xie, C.J.; Guo, Z.X.; Qiu, T.; Tuo, X.L. Construction of Aramid Engineering Materials via Polymerization-Induced para-Aramid Nanofiber Hydrogel. Adv. Mater. 2021, 33, e2101280. [CrossRef]

29. Guo, H.; Li, Y.; Ji, Y.; Chen, Y.; Liu, K.; Shen, B.; He, S.; Duan, G.; Han, J.; Jiang, S.J.C.C. Highly flexible carbon nanotubes/aramid nanofibers composite papers with ordered and layered structures for efficient electromagnetic interference shielding. Compos. Commun. 2021, 27, 100879. [CrossRef]

30. Yang, B.; Wang, L.; Zhang, M.Y.; Lu, Z.Q.; Tan, J.J.; Luo, J.L.; Lu, P. Water-resistant, transparent, uvioresistant cellulose nanofiber (CNF)-aramid nanofiber (ANF) hybrid nanopaper. Mater. Lett. 2019, 240, 165-168. [CrossRef]

31. Yang, B.; Zhang, M.Y.; Lu, Z.Q.; Tan, J.J.; Luo, J.J.; Song, S.X.; Ding, X.Y.; Wang, L.; Lu, P.; Zhang, Q.Y. Comparative study of aramid nanofiber (ANF) and cellulose nanofiber (CNF). Carbohydr. Polym. 2019, 208, 372-381. [CrossRef] [PubMed]

32. Yang, M.; Cao, K.Q.; Sui, L.; Qi, Y.; Zhu, J.; Waas, A.; Arruda, E.M.; Kieffer, J.; Thouless, M.D.; Kotov, N.A. Dispersions of Aramid Nanofibers: A New Nanoscale Building Block. ACS Nano 2011, 5, 6945-6954. [CrossRef] [PubMed]

33. Lyu, J.; Wang, X.Z.; Liu, L.H.; Kim, Y.; Tanyi, E.K.; Chi, H.; Feng, W.C.; Xu, L.Z.; Li, T.H.; Noginov, M.A.; et al. High Strength Conductive Composites with Plasmonic Nanoparticles Aligned on Aramid Nanofibers. Adv. Funct. Mater. 2016, 26, 8435-8445. [CrossRef]

34. Zhu, J.; Yang, M.; Emre, A.; Bahng, J.H.; Xu, L.Z.; Yeom, J.; Yeom, B.; Kim, Y.; Johnson, K.; Green, P.; et al. Branched Aramid Nanofibers. Angew. Chem. -Int. Ed. 2017, 56, 11744-11748. [CrossRef]

35. Tung, S.O.; Ho, S.; Yang, M.; Zhang, R.L.; Kotov, N.A. A dendrite-suppressing composite ion conductor from aramid nanofibres. Nat. Commun. 2015, 6, 6152. [CrossRef]

36. Jung, J.; Sodano, H.A. High strength epoxy nanocomposites reinforced by epoxy functionalized aramid nanofibers. Polymer 2020, 195, 122438. [CrossRef]

37. Li, J.Y.; Lu, Z.Q.; Xie, F.; Huang, J.Z.; Ning, D.D.; Zhang, M.Y. Highly compressible, heat-insulating and self-extinguishing cellulose nanofiber/aramid nanofiber nanocomposite foams. Carbohydr. Polym. 2021, 261, 117837. [CrossRef]

38. Yang, B.; Wang, L.; Zhang, M.Y.; Li, W.W.; Zhou, Q.K.; Zhong, L.X. Advanced separators based on aramid nanofiber (ANF) membranes for lithium-ion batteries: A review of recent progress. J. Mater. Chem. A 2021, 9, 12923-12946. [CrossRef]

39. Zhou, Y.; Wang, S.J.; Li, D.S.; Jiang, L. Lightweight and recoverable ANF/rGO/PI composite aerogels for broad and highperformance microwave absorption. Compos. Part B-Eng. 2021, 213, 108701. [CrossRef]

40. Han, X.; Wang, Z.; Ding, L.; Chen, L.; Wang, F.; Pu, J.; Jiang, S. Water molecule-induced hydrogen bonding between cellulose nanofibers toward highly strong and tough materials from wood aerogel. Chin. Chem. Lett. 2021, in press. [CrossRef]

41. Sluiter, A.; Hames, B.; Ruiz, R.; SCarlata, C.; Sluiter, J.; TempletOn, D.; Crocker, D. Determination of structural carbohydrates and lignin in biomass. Lab. Anal. Proced. 2008, 1617, 1-16.

42. Yang, X.; Berthold, F.; Berglund, L.A. High-Density Molded Cellulose Fibers and Transparent Biocomposites Based on Oriented Holocellulose. ACS Appl. Mater. Interfaces 2019, 11, 10310-10319. [CrossRef] [PubMed] 
43. Hervy, M.; Santmarti, A.; Lahtinen, P.; Tammelin, T.; Lee, K.Y. Sample geometry dependency on the measured tensile properties of cellulose nanopapers. Mater. Des. 2017, 121, 421-429. [CrossRef]

44. Segal, L.; Creely, J.J.; Martin, A., Jr.; Conrad, C. An empirical method for estimating the degree of crystallinity of native cellulose using the X-ray diffractometer. Text. Res. J. 1959, 29, 786-794. [CrossRef]

45. Lu, Z.Q.; Si, L.M.; Dang, W.B.; Zhao, Y.S. Transparent and mechanically robust poly (para-phenylene terephthamide) PPTA nanopaper toward electrical insulation based on nanoscale fibrillated aramid-fibers. Compos. Part A-Appl. Sci. Manuf. 2018, 115, 321-330. [CrossRef]

46. Si, L.M.; Lu, Z.Q.; Yao, C.; Ma, Q.; Zhao, Y.S.; Wang, Y.F.; Wang, D.N.; Jin, Z.F. Nacre-like nanocomposite film with excellent dielectric insulation properties and mechanical strength based on montmorillonite nanosheet and aramid nanofiber. J. Mater. Sci. 2020, 55, 5948-5960. [CrossRef]

47. Zong, P.J.; Jiang, Y.; Tian, Y.Y.; Li, J.; Yuan, M.; Ji, Y.Y.; Chen, M.S.; Li, D.W.; Qiao, Y.Y. Pyrolysis behavior and product distributions of biomass six group components: Starch, cellulose, hemicellulose, lignin, protein and oil. Energy Convers. Manag. 2020, 216, 112777. [CrossRef]

48. Lu, Y.X.; Tao, P.; Zhang, N.; Nie, S.X. Preparation and thermal stability evaluation of cellulose nanofibrils from bagasse pulp with differing hemicelluloses contents. Carbohydr. Polym. 2020, 245, 116463. [CrossRef] [PubMed]

49. Yang, B.; Wang, L.; Zhang, M.Y.; Luo, J.J.; Lu, Z.Q.; Ding, X.Y. Fabrication, Applications, and Prospects of Aramid Nanofiber. Adv. Funct. Mater. 2020, 30, 2000186. [CrossRef]

50. Patterson, B.A.; Malakooti, M.H.; Lin, J.J.; Okorom, A.; Sodano, H.A. Aramid nanofibers for multiscale fiber reinforcement of polymer composites. Compos. Sci. Technol. 2018, 161, 92-99. [CrossRef] 